\title{
Risk management to reduce livestock losses from toxic plants
}

\author{
JAMES A. PFiSTER, FRED D. PROVENZA, KIP E. PANTER, BRYAN L. STEGELMEIER, AND KAREN L. \\ LAUNCHBAUGH
}

Pfister, Panter, and Stegelmeier are Rangeland Scientist, Research Animal Scientist, and Veterinary Pathologist, respectively, with the USDA-ARS Poisonous Plant Research Laboratory, Logan, Utah 84341. Provenza is Professor, Rangeland Resources Department, Utah State University, Logan, Utah 84322. Launchbaugh is Assistant Professor, Department of Rangeland Resources, University of Idaho, Moscow, Idaho 83844. Pfister's email: jpfister@cc.usu.edu

\begin{abstract}
Risk of livestock losses to poisonous plants can be reduced on many ranges through prudent management based on application of existing knowledge. Poisonous plants can be categorized using both acceptability to livestock and a plant's toxic potential. Acceptability encompasses forage qualities such as taste and chemistry (i.e., nutrient and toxin concentrations) and postingestive feedback from an animal's daily and long-term (e.g., body condition) nutritional and toxicological state. Toxic potential reflects aspects of plant chemistry, including seasonal or other changes in concentration or functionality of the toxin(s), and type of toxicity (i.e., acute or chronic). Persistent livestock losses to poisonous plants may indicate that ranges are over-grazed or improperly managed. Aggressive management schemes that employ high stocking rates and grazing intensities may yield greater returns, but may also increase risk if poisonous plants are present. Plants may be ranked according to toxicity and acceptability. Six interrelated categories of plants are discussed: 1) always toxic and acceptable to livestock; 2) always toxic and not acceptable; 3) always toxic and acceptable at certain times; 4) toxic only at certain times and acceptable to livestock; 5) toxic at certain times and unacceptable; and 6) toxic at certain times and acceptable at certain times. Each category involves differing risk and uncertainty. Within this management matrix, strategies for dealing with specific poisonous plants can be customized depending on how much and when the plant is eaten by livestock, and when the plant is most toxic.
\end{abstract}

Key Words: grazing management, diet selection, poisonous plants

"Nature has established patterns originating in the return of events, but only for the most part" (von Leibniz 1703). How closely humans pay attention to the patterns generated by past events, and use that information to understand risk and make rational decisions, often determines success or failure at many of life's junctures, including grazing livestock on ranges with toxic plants. Interestingly, the earliest form of gambling used a type of

Invited paper presented at a symposium "Do most livestock losses to poisonous plants result from 'poor' range management?" held in Boise, Ida., February 16, 2000 .

Manuscript accepted 25 May 01.
Resumen

El riego de perdidas de ganado por plantas tóxicas puede ser reducido en muchos pastizales a través de un manejo prudente basado en la aplicación del conocimiento existente. Las plantas tóxicas pueden ser categorizadas usando la aceptabilidad por el ganado y un potencial tóxico de la planta. La aceptabilidad incluye las cualidades del forraje tales como sabor y química (nutrientes y concentraciones de toxinas) y la retroalimentación postingestiva del estado nutricional y toxicológico diario y de largo plazo (condición corporal) del animal. El potencial tóxico refleja aspectos de la química de la planta, incluyendo cambios estacionales o de otra naturaleza en la concentración o funcionalidad de la toxina(s) y el tipo de toxicidad (aguda o crónica). Perdidas persistentes de ganado por plantas toxicas pueden indicar que los pastizales están sobreutilizados o manejados impropiamente. Los esquemas agresivos de manejo que emplean cargas animal e intensidades de apacentamiento altas pueden en rendir grandes retornos, pero pueden también incrementar el riesgo si las plantas toxicas están presentes. Las plantas pueden ser clasificadas de acuerdo a la toxicidad y aceptabilidad. Se discuten 6 categorías interrealcionadas de plantas: 1) siempre tóxica y aceptable por el ganado; 2) siempre tóxica y no aceptable ; 3) siempre tóxica y aceptable en ciertas ocasiones; 4) tóxica solo en ciertas ocasiones y aceptada por el ganado; 5) tóxica en ciertas ocasiones y no aceptable y 6) tóxica en ciertas ocasiones y aceptable en ciertas ocasiones. Cada categoría involucra diferente riesgo e incertidumbre. Dentro de esta matriz de manejo, las estrategias para tratar con plantas tóxicas especificas pueden ser personalizadas dependiendo de que tanto y cuando la planta es comida por el ganado y cuando la planta es más tóxica.

dice known as an "astragalus" (Bernstein 1996). Rather than a genus of toxic plant, this astragalus was the squarish, virtually indestructible, talus or ankle bone taken from sheep. Games of chance and grazing ranges infested with toxic plants are activities rife with elements of risk and need for thoughtful decision-making. Risk is derived from the Latin risicare meaning 'to dare.' Grazing livestock on ranges with poisonous plants should not entail excessive risk, providing managers take the best available information, combine it with personal experience, and make rational choices.

Can all losses to poisonous plants be avoided? Probably not. In spite of advancements such as analyses for toxic compounds, 
knowledge of consumption patterns, and predictive quantitative models lighting the way, the data for decision-making come from an imperfect or "only for the most part" past. Creatures, plants, and the environment are dynamic and continually interacting, thus, decision-making will never be perfect. Nonetheless, knowledge improves the odds in gambling and grazing. Therefore, research-based decision-making can reduce risks and losses. The objective of this paper is to review management insights and options that may reduce the likelihood of livestock consuming lethal or debilitating amounts of poisonous plants.

\section{A Management Matrix}

Poisonous plants can be simultaneously categorized using both acceptability to livestock and toxic potential (Merrill and Schuster 1978, Fig. 1). We use the term "acceptability" as an expression integrating palatability and preference to avoid the misleading connotations associated with the latter terms (Provenza et al. 1998). Acceptability in this paper encompasses forage qualities such as taste and nutrient or toxin concentrations and postingestive feedback. Postingestive feedback results from an animal's short-term (e.g., withinday energy status) and long-term (e.g., body condition) nutritional (Provenza 1995) and toxicological states (Kingsbury 1978). These forage qualities and feedback therefore directly and indirectly influence forage intake (Provenza et al. 1992, Provenza 1995). Acceptability within the foraging milieu is influenced greatly by an animal's past experiences such as social and environmental interactions (Provenza et al. 1992, 1993). Toxic potential reflects primarily aspects of plant chemistry, including seasonal or other changes in concentration or functionality of the toxin(s), and the type of induced toxicity (e.g., acute or chronic). As we view it, a plant's toxic potential does not involve postingestive feedback or impacts on diet selection.

\section{Management Factors That Influence Risk}

Acceptability of toxic plants

Various stressors affect the selection of toxic plants by livestock. When naive animals are introduced into unfamiliar pastures they often ingest more toxic plants than experienced animals on the same ranges (Schuster 1978, Krueger and Sharp 1978). Naive animals first introduced into large pastures usually display increased exploratory behavior and reduced ability to prehend forage (Arnold and Maller 1977) and may simultaneously broaden diet selection thresholds so that normally avoided toxic plants are then eaten (Strydom and Joubert 1983, Kellerman 1987, Fredrickson et al. 2000). Animals are also more likely to eat familiar, toxic plants in unfamiliar settings (Burritt and
Provenza 1997). Further, animals under stress may not only ingest more toxic plants, but they may be less able to degrade or tolerate toxins because stress effects various body systems (Freeland and Janzen 1974, Foley et al. 1995, Illius and Jessop 1995). Naive animals initially exposed to some toxic plants may be more vulnerable because of reduced detoxification abilities either from a lack of adapted rumen microbes (Duncan et al. 2000) or a lack of inducible enzyme systems (Galtier 1999). In contrast, experienced animals, including insects, may consume plants containing toxins to which they are partially or completely adapted (Harborne 1988). For example, kangaroos (Macropus spp.) tolerate plants containing the highly toxic fluoracetate, yet given a choice between Gastrolobium species with high and low concentrations of fluoracetate, kangaroos feed primarily on the plant with lower amounts (Mead et al. 1985).

The acceptability of toxic plants may also be affected by daily levels of energy or nutrient intake. Ruminant livestock react very quickly to short-term nutrient stress and alter diet selection to compensate (Villalba and Provenza 1999a, 1999b). Typical short-term nutrient stress may be triggered by day-to-day excesses or deficits of protein or energy (Cooper et al. 1993, Kyriazakis and Oldham 1993, Villalba and Provenza 2000, Cosgrove and Niezen 2000). Ruminants select for foods higher in protein or energy when eating

\begin{tabular}{|l|l|l|l|}
\hline Always Toxic & $\begin{array}{l}\text { Generally } \\
\text { Acceptable to } \\
\text { Livestock }\end{array}$ & $\begin{array}{l}\text { Generally Unacceptable } \\
\text { to Livestock }\end{array}$ & $\begin{array}{l}\text { Acceptable only at } \\
\text { Certain Times }\end{array}$ \\
Oxytropis spp. & $\begin{array}{l}\text { Hymenoxys } \text { odorata } \\
\text { Senecio } \text { spp. } \\
\text { Asclepias spp. } \\
\text { Pteridium aquilinum } \\
\text { Nicotiana } \text { spp. } \\
\text { Hypericum perforatum }\end{array}$ & $\begin{array}{l}\text { Halogeton } \text { glomeratus } \\
\text { Pinus ponderosa } \\
\text { Veratrum } \text { spp. } \\
\text { Solanum } \text { spp. } \\
\text { Zigadenus spp. }\end{array}$ \\
\hline $\begin{array}{l}\text { Toxic Only at } \\
\text { Certain Times }\end{array}$ & $\begin{array}{l}\text { Quercus spp. } \\
\text { Lupinus } \text { spp. } \\
\text { Prunus virginianus } \\
\text { Cicuta } \text { spp. }\end{array}$ & Tetradymia spp. & $\begin{array}{l}\text { Delphinium } \text { spp. } \\
\text { Conium maculatum }\end{array}$ \\
\hline
\end{tabular}

Fig. 1. A management matrix or framework to simultaneously categorize toxic plants according to both acceptability to livestock and the toxic potential of the plant. 
meals low in these nutrients (Villalba and Provenza 1999a, 1999b) or when parasite loads cause metabolic protein deficiency (Cosgrove and Niezen 2000).

Providing supplemental protein or energy may raise the threshold at which animals are intoxicated (Illius and Jessop 1995), allowing animals to ingest more of such toxins as terpenes (Villalba et al. 2000a) and tannins (Villalba et al. 2000b). Supplements may also aid in detoxification once a toxin is ingested. Polyethelene glycol (PEG) binds irreversibly to tannin compounds, and has been successfully added to both feed and water to improve intake of tannin-containing shrubs in the U.S. and in Israel (Priolo et al. 2000, Titus et al. 2000). Activated charcoal adsorbs some plant toxins and allows livestock to increase intake of toxic bitterweed (Poage et al. 2000) and terpene-laden sagebrush (Villalba et al. 2000a).

Long-term nutrient stress or low body condition may also impact diet selection (Tayler 1959). Animals in poor body condition may expand diet selection to include poorly acceptable poisonous plants (Noble et al. 1994, Hancock et al. 1996, Pascual et al. 1999). Conversely, animals in good body condition may restrict intake of poor quality (Foot 1972) or toxic plants.

Either short- or long-term nutrient stress may have other implications for diet selection. First, animals under nutritional stress may be less able to detoxify plant toxins (Illius and Jessop 1995, 1996) and may suffer relatively greater harm from the metabolic effects of the toxin (Freeland and Janzen 1974, Foley et al.1999). Conversely, animals in good body condition that eat toxic plants may have enhanced abilities to tolerate or detoxify some toxins, and may suffer fewer negative postingestive consequences when they consume poisonous plants. Much of the detoxification that occurs in the liver, for example, is inducible, and depends partially on nutrients or metabolites to enhance or facilitate degradation (Illius and Jessop 1995). Detoxification requires additional nutrients to allow body systems to alter toxins and maintain acid-base equilibrium (Illius and Jessop 1995, Jessop and Illius 1997, Foley et al. 1999). For example, low protein diets decrease the amount and activity of detoxification activity in the liver (e.g., cytochrome P450 enzyme system, McLean and McLean 1969).

Poorly nourished animals on some ranges may be stressed by shortages of energy and protein, and be in poor body condition. These animals may experience hunger to such an extent that they increase intake of toxic plants in spite of potentiated negative feedback (Provenza 1995). In this case, one would expect substantial increases in dead or impaired animals (Meyer and Karasov 1991). Some of the catastrophic livestock losses (e.g., Chesnut and Wilcox 1901) that occurred in the late 1800 's and early 1900's may be attributed to this type of situation. Interestingly, if animals survive a toxic insult, they may later eat less of the toxic plant because of the potentiated gastrointestinal feedback.

Persistent livestock losses to poisonous plants may indicate that ranges are either degraded or seasonally over-utilized (Merrill and Schuster 1978, Holechek 2002, Ralphs 2002). Even temporary excess utilization may induce livestock losses as grazing animals consume otherwise poorly acceptable poisonous plants (Schuster 1978). Many toxic plants are not highly preferred when other desirable forages are available (Taylor and Ralphs 1992). Even if animals eat small amounts of many poisonous plants, they will suffer few ill effects if other nontoxic forage makes up the majority of their diet because of low amounts of a toxin, and the influence of nutrients as discussed above. Management-intensive grazing systems also generally increase the likelihood of poisonous plant losses when management errors foster short-term over-utilization and/or hungry livestock (Merrill and Schuster 1978). Aggressive management schemes that employ higher stocking rates and grazing intensities may yield greater returns, but also increase risks of poisoning if toxic plants are present; toxic plants may also proliferate under intensive grazing schemes (Holechek 2002).

Why do animals return to eat a plant that has been aversive in the past? Generalist herbivores, including range livestock, have a natural propensity to sample plants in their environment (Westoby 1974). When ingestion of a toxic plant in small amounts causes no or few negative effects, animals are likely to increase consumption of the plant. In addition, many toxic plants contain substantial nutritional value (larkspur: Pfister et al. 1989, locoweed: Ralphs and Molyneux 1989) and provide positive digestive feedback. Both locoweed (Astragalus lentiginosus Doug. ex Hook.) and plains larkspur (Delphinium geyeri Greene) contain more than $20 \%$ crude protein early in the spring (Pfister unpublished observations). Eating some of a toxic plant provides needed nutrients with little toxicity, but increased consumption results in heightened adverse effects because of the dose-response characteristic of many toxins. Partial avoidance or "partial preference" (Day et al. 1998) for a toxic forage would likely result in a grazing animal eating variable but increasing quantities of the forage, until negative feedback from toxins, or excess of nutrients (Provenza 1996) became sufficiently strong to temporarily drive the animal "off" the feed (e.g., larkspur; Pfister et al. 1997a). Each time a toxic forage is eaten without negative consequences, the aversion is weakened and will eventually vanish without additional negative feedback (Lane et al. 1990, Ralphs and Stegelmeier 1998). Aversions are generally dose-dependent, and stronger aversions are formed to compounds that create intense illness (duToit et al. 1991, Ralphs and Cheney 1993, Launchbaugh and Provenza 1994).

\section{Concentration of plant toxins}

Management of toxic plants is usually easier and more successful when the toxin is known, and management schemes can be devised to take advantage of seasonal patterns and reduced toxicity (e.g., larkspur: Pfister et al. 1994, Gardner and Pfister 2000). Toxicity of plants is usually related to a specific compound, and in the case of reproductive effects, animals are poisoned at specific physiological stages when they eat plants such as lupine (Lupinus spp.) or veratrum (Veratrum spp.; Panter et al. 1992, Panter et al. 2002). Pfister et al. (1988, 1997b) identified a toxic window when most deaths from tall larkspur (Delphinium barbeyi Huth.) occur, and also determined that an early grazing period is relatively risk-free even though larkspur alkaloid concentrations are high. Cattle typically eat little or no tall larkspur before larkspur elongates flowering racemes, providing a 4 to 6 week low-risk period for grazing. Many producers, however, put cattle into larkspur-infested pastures when the plant is flowering and the risk is higher, even though consumption by cattle usually increases during the flower stage of growth (Pfister et al. 1988). Conversely, late in the grazing season, the risk of grazing tall larkspur-infested ranges is also relatively low; even though cattle eat large quantities of larkspur during the pod stage, once the pods dry out, the alkaloid concen- 
tration is low (Gardner and Pfister 2000).

Does the concentration of a particular toxin alter the likelihood that livestock will graze the plant? Many plant toxins, such as alkaloids, are reported to taste bitter (Bate-Smith 1972), whereas tannin-rich plants are typically astringent (Harborne 1988). There are apparently large differences in the taste responses of livestock species to bitter and astringent solutions (Arnold and Hill 1972). Goats appear to be less sensitive to bitter than are sheep, and cattle are least sensitive, whereas catthe are most sensitive and sheep the least sensitive to astringent solutions (Arnold and Hill 1972). These conclusions must be viewed with caution because taste thresholds and postingestive feedback were confounded. Garcia and Hankins (1975) argued that animals inherently avoid most alkaloids because a bitter taste is often linked with toxicity. Some forage plants such as reed canarygrass (Phalaris arundinaceae L.) and certain lupines are unpalatable because of high alkaloid concentrations (Ralphs and Olsen 1987). Nonetheless, Robinson (1979), Glendinning (1994), and Nolte et al. (1994) concluded that alkaloids are not universally repellent to herbivores. Additionally, Molyneux and Ralphs (1992) suggest that some toxic alkaloids are not bitter tasting to livestock.

Pfister et al. (1996a) found that high concentrations of toxic alkaloids in tall larkspurs have essentially no impact on how much tall larkspur is eaten by cattle in the short-term, and that postingestive feedback, not flavor, regulates larkspur intake (Pfister et al. 1990). Cattle that consume high concentrations of tall larkspur alkaloids experience negative postingestive feedback from the nutritious larkspur plants (Pfister et al. 1990), leading to a cyclic pattern of intake with 1 to 2 days of high consumption followed by several days of low or no larkspur intake (Pfister et al. 1997a). Sheep are relatively resistant to poisoning from larkspur alkaloids, and in contrast to cattle, sheep intake of larkspur is negatively affected by higher alkaloid concentrations (Pfister et al. 1996a).

\section{Toxic plants within a management matrix}

Always toxic and generally acceptable to livestock

Locoweeds (Astragalus and Oxytropis spp.) are widespread on rangelands in the western U.S. They contain the toxic indolizidine alkaloid swainsonine.
Abundant winter and spring moisture causes rapid growth of locoweed before cool season grasses have initiated growth. Locoweeds are difficult to manage because 1) they are readily eaten by livestock once consumption begins (Ralphs et al. 1993), 2) swainsonine is found in both green and dry material (Ralphs and Molyneux 1989), 3) very low concentrations of swainsonine are toxic if ingested continuously over several weeks (Pfister et al. 1996b), and 4) cattle often select locoweeds in preference to dry dormant forages (Ralphs et al. 1997). Two recently determined characteristics of locoweed have potential to provide management options not recognized in the past. First, swainsonine is quickly excreted from animals once they stop ingesting locoweeds (Stegelmeier et al. 1995a); and second, swainsonine has a "threshold" effect in that once sufficient toxin is consumed, all susceptible enzymes within cells are inhibited, so ingesting more swainsonine does not lead to greater damage or enzyme inhibition (Stegelmeier et al. 1995b). Taken together, these characteristics of swainsonine indicate that it may be possible to formulate "on-off" or cyclic grazing systems such that livestock are grazed for 10-14 days on locoweed-infested ranges, then allowed at least 14 days for detoxification (Stegelmeier, unpublished data). Ingestion of even a small amount of locoweed leads to tissue damage (Van Kampen and James 1970), particularly in the central nervous system where rapid injury may be expected (McFarlane et al. 2000). Lesions may be subtle, however, and resolve quickly once animals are removed from locoweed (Huxtable et al. 1982, Pfister et al. 1996b, Stegelmeier unpublished data). An "on-off" grazing scheme may allow animals to eat some locoweed without hitting an irreversible toxic threshold and thereby avoid permanent tissue damage (Stegelmeier, unpublished observations).

Simple changes in grazing management may provide remarkable benefits with locoweed. Producers in northern Utah graze cattle each summer on high elevation ranges in the Raft River Mountains. For many years, the producers used a rest rotation grazing system, wherein 3 pastures were grazed in sequence, and 1 pasture was rested each summer. Range condition improved over a 10 -year period (Ralphs et al. 1984), yet annual losses to locoweed (Oxytropis sericea Nutt. in T. \& G.) exceeded $20 \%$. Based on observations that most consumption of locoweed occurred after flowering during August, the grazing season was reduced from 71 to 47 days, cattle numbers were increased, and the grazing method was altered to a Merrill 3-herd, 4 pasture system (Ralphs et al. 1984). Changing the grazing system reduced animal density and resulted in less locoweed eaten. As a result, yearly losses declined to about $3 \%$. These simple changes altered diet selection and dramatically reduced losses, as cattle were no longer forced to eat locoweed.

\section{Always toxic and generally not acceptable to livestock}

Consumption of toxic plants in this category is usually linked to a managementdriven crises such as lack of forage from drought and overgrazing. Periodic droughts occur frequently in much of western North America, and astute livestock producers maintain a forage reserve. The lack of forage contributes significantly to consumption of plants in this category, as these plants are not likely to be eaten to excess unless animals are forced to consume them (Merrill and Schuster 1978). With proper management, losses should be few because of the low acceptability of species such as senecios (Senecio spp.), bitterweed (Hymenoxys odorata DC.), and milkweeds (Asclepias spp.). Losses from species in this category may be linked to consumption of dried toxic material in hay (Baker et al. 1989).

Most of the losses to Senecio spp. occur from 3 species: S. jacobaea L., S. longilobis Benth., and S. riddellii T. \& G. (Kingsbury 1964). These plants contain pyrrolizidine alkaloids (PA), sometimes in large quantities (e.g., 18\% of dry weight, Molyneux and Johnson 1984). Ingestion of even small quantities of PAs causes liver damage that is cumulative over many months (Stegelmeier 1999). Because Senecio spp. are generally not acceptable to livestock, cattle and horse losses usually occur from chronic intoxication when they eat small quantities over several weeks when other forage is lacking (Sharrow et al. 1988). Sheep and goats are relatively resistant to senecio poisoning (Stegelmeier 1999). Affected animals may show only mild depression and poor performance until they show clinical signs; once clinical signs are apparent animals rarely recover (Johnson et al. 1985). Losses to Senecio spp. can be minimized through proper range management and careful 
planning for periodic drought (Sharrow et al. 1988) and ensuring that hay is free from senecio.

Milkweeds (Asclepias spp.) are perennial forbs that generally are not acceptable to livestock unless other forage is scarce or it is eaten in hay. The principal toxic species in the western U.S. are A. subverticillata (Gray) Vail, A. eriocarpa Benth., A. fascicularis Decne. in DC, and A. labriformis Jones. The latter plant contains cardiac glycosides (cardenolides), potent toxins that disrupt heart function. Preventive management entails maintaining rangelands in good condition, and ensuring that hungry livestock do not have access to the plant.

\section{Always toxic and acceptable only at certain times to livestock}

Halogeton glomeratus (Bieb) C.A. Mey. is an annual forb that invaded desert rangelands in the western U.S. Halogeton is responsible for large losses of sheep, particularly during the 1940's and 1950's (Young et al. 1999). Halogeton contains sodium and potassium oxalates, which if ingested in high enough amounts cause acute hypocalcemia and impairment of cellular enzymes leading to death. Halogeton is acceptable to cattle and sheep, particularly when sheep are hungry and not thirsty. Acceptability of halogeton also increases when animals are salt deprived (Young et al. 1999). At times, halogeton may be an important forage source for adapted sheep grazing desert rangelands (James and Cronin 1974). Sheep gradually introduced to oxalatecontaining plants over several days can be adapted to high oxalate-containing plants with low risk (James and Cronin 1974). Overgrazing of rangelands can lead to plant community disturbance and increased populations of halogeton, resulting in fewer alternative forages and greater likelihood of poisoning. Excessive stocking rates can also increase halogeton losses, as sheep have fewer alternative forage sources (James and Cronin 1974). Virtually all the large losses of sheep to halogeton poisoning can be attributed to poor management (Young et al. 1999).

Ponderosa pine (Pinus ponderosa Law.) occurs throughout western North America. Pregnant cattle that ingest pine needles or bark during mid- to late-gestation are at risk of aborting their calves (James et al. 1989). The toxic in pine needles and bark is a diterpene resin acid, isocupressic acid (Gardner et al. 1999). The toxin presum- ably restricts blood flow to the fetus, leading to fetal stress and abortion (or early birth). Consumption of pine needles by cattle is greatest during cold winter temperatures coinciding with reduced amounts of available forage, either from snow cover or previous grazing (Pfister and Adams 1993, Pfister et al. 1998). Although this implies that cattle eat pine needles from hunger, our observations indicate that this is not the case. We have observed cattle leave winter feeding grounds with hay remaining to forage in stands of pine trees (Pfister, personal observations). Field and pen studies at our laboratory suggest that most cattle acquire a preference for pine needles, even if they initially refuse to eat fresh green needles (Pfister, Villalba, and Provenza, unpublished data). There are several management options that reduce the risk of abortions. First, because cattle are more susceptible to abortions as gestation advances, a prudent management option is to limit cattle exposure to pine trees once cattle have entered the third trimester of gestation (Short et al. 1992). If that is not possible, our observations suggest that risk is reduced by ensuring that the pasture has adequate forage not covered by snow (Pfister, personal observations). If snow cover is too deep, supplementation can substitute for some forage, and be timed to disrupt daily grazing patterns (Adams et al. 1986) to reduce cattle grazing in areas with pine trees (Pfister, personal observations). Because cattle learn to like pine needles, producers with serious losses should also consider changing calving dates from spring to fall, thereby moving late-gestation to summer when cattle are less likely to eat pine needles (Uresk and Paintner 1985). Another option is to delay winter calving into late spring (e.g., May or June). Cattle eat few pine needles as air temperatures warm, snow cover disappears, and cool season grasses begin growth during March and April (Pfister, unpublished observations).

Steroidal veratrum-type alkaloids are found in species of Veratrum (false hellebore) and Zigadenus (death camas). Ingestion of false hellebore by pregnant sheep on gestation day 14 results in "monkey-faced" or cyclopian lambs with potentially severe craniofacial defects (Binns et al. 1962). Sheep are primarily affected because of their propensity to eat false hellebore (Keeler 1983). Cattle rarely eat the plant, and no special management is needed to reduce consumption. Sheep management to avoid losses to false hellebore is relatively simple (Panter et al. 2002). First, because the window of fetotoxicity is relatively narrow between 14 to 33 days gestation, pregnant animals should not be allowed access to veratruminfested pastures for about 1 month after the rams are removed (Keeler 1983, Panter et al. 1992). This is not difficult to accomplish because false hellebore is limited in distribution to moist mountain habitats, is easy to identify, and grows in dense patches.

Death camas (Zygadenus spp.) is one of the first plants to grow during spring on foothill rangelands, and animals may graze the plant if other forage is lacking. Death camas toxicity is characterized by excessive salivation, frothing around the mouth, nausea and sometimes vomition (Kingsbury 1964, Panter et al. 1987). If the dose is sufficient, muscular weakness is followed by ataxia, recumbency, and death from heart failure. Generally, recognizing the presence of death camas and understanding the acutely toxic nature of the plant will aid in avoiding problems. Losses occur sporadically on foothill ranges. Panter et al. (1987) identified 3 contributing circumstances that contributed to a loss of over 250 sheep in 1 band. First, hungry ewes with lambs were driven through death camas-infested pasture. Second, sheep were bedded near death camas, so the plant was readily available for grazing. Third, the herder stressed the sheep by rapidly driving them from the area, thus increasing the death loss (Panter et al. 1987).

\section{Toxic only at certain times, and gener- ally acceptable to livestock}

Lupines (Lupinus spp.) are both toxic and teratogenic (i.e., causing birth defects) to livestock (Panter and James 1995). Some lupines contain quinolizidine alkaloids that cause acute respiratory failure in sheep (Kingsbury 1964). Lupine toxicity is seen clinically as a neurologic disease that progresses from depression and lethargy to muscular weakness, collapse, respiratory failure and death (Panter et al. 1999). Birth defects are apparently caused by the effects of 2 different, but related, alkaloids, anagyrine and ammodendrine (Keeler 1978, Panter et al. 1992, Panter et al. 2002). For unknown reasons, cattle are uniquely sensitive to the effects of anagyrine, and ingestion of alkaloid-rich lupines (Lupinus laxiflorus Douglas ex 
Lindl., L. caudatus Kellogg, and $L$. sericea Pursh) causes the condition "crooked calf disease" in cattle (Shupe et al. 1967, Keeler 1989, Panter et al. 1994). Losses of livestock can largely be prevented by understanding 2 interrelated aspects of lupine poisoning. First, the highest concentrations of toxic alkaloids occur in immature lupine plants and seed pods. Anagyrine concentrations are highest ( $>5$ $\mathrm{mg} / \mathrm{g}$ ) in early growth, and decline to less than $0.5 \mathrm{mg} / \mathrm{g}$ after seed shatter, except that concentrations increase in seeds as lupine matures (Keeler 1976). Second, pregnant cattle are susceptible to the teratogenic effects of alkaloids during a window from days 40 to 70 of gestation, occasionally extending to 100 days (Shupe et al. 1967, Panter et al. 1997). Birth defects in cattle can be prevented by using breeding or grazing programs that avoid placing pregnant cattle in lupine-dominated pastures in the first trimester of gestation (Keeler et al. 1977, Panter et al. 1992, Panter et al. 2002). Alternatively, risk can be reduced by allowing only short-term access to lupines by pregnant cattle in some form of rotational grazing (Panter et al. 1999).

Acute toxicity problems from lupine are less common now, but large sheep losses occurred frequently 100 years ago (Chesnut and Wilcox 1901). Deaths occur when livestock, usually sheep, ingest a large amount of seed pods in a short time period (James et al. 1968). This can be prevented by using lupine-free hay and avoiding lupine-dominated ranges when alternative forage is scarce.

Water hemlocks (Cicuta spp.) are the most acutely toxic plants in North America; the toxin is a long-chain alcohol named cicutoxin. The large tuber is most toxic, and above ground parts are less toxic. Toxicity of tubers decreases with maturation, and dry stems and leaves are relatively non-toxic (Panter et al. 1988). Green seeds may be toxic (Panter, personal observations), although dry seeds are not toxic to hamsters (Panter, unpublished data). During the spring, the immature plant and tubers are generally well accepted by livestock, particularly cattle, as water hemlock begins growth before other plants (Panter et al. 1988). Affected animals show increased respiration, excessive salivation, nervousness, and tremors progressing to siezures and death (Panter et al. 1996). Most losses to water hemlock can be avoided if livestock producers identify and destroy water hemlock plants along streams, ditches or in swamps. Because tubers are easily exposed in moist soil, and are less toxic when mature, keeping livestock away from the plant during spring when the soil is wet and soft prevents most poisonings.

Oak brush (Quercus spp.) includes numerous species in western North America. The primary toxic species are $Q$. gambelii Nutt., $Q$. havardii Rydb., $Q$. undulata Torr., and $Q$. turbinella Greene, but many other species may cause problems at specific times (Basden and Dalvi 1987). The toxins are thought to be polyphenolic tannins (Panciera 1978). Clinical signs include anorexia, rumen atony and constipation, followed by gastroenteritis and diarrhea. Pathological lesions usually involve acute kidney failure (Panciera 1978). Chronic consumption of excessive oak brush can lead to kidney and liver disease; producers in west Texas label such animals "shinneried" because they have become poisoned on shinnery oak ( $Q$. havardii). Immature leaves, buds, and recently fallen acorns are typically more toxic and more acceptable to livestock than are mature leaves and dry acorns (Panciera 1978). Cattle can consume large amounts (50\% of their diet) of oak brush without serious effects (Dollahite et al. 1966), thus management can be directed toward keeping oak consumption below toxic levels. This is accomplished by ensuring that livestock have adequate amounts of alternative forages during spring when immature leaves are available, and during autumn when acorns fall. When livestock consume large amounts of oak brush, supplementation with calcium hydroxide (10\%, Dollahite et al. 1966) or polyethylene glycol (Titus et al. 2000) can help prevent toxicosis.

\section{Toxic only at certain times and gener- ally unacceptable to livestock}

Plants that are toxic only at certain times and are generally unacceptable to livestock are relatively easy to manage with proper grazing practices. Snakeweeds (Gutierrizia spp.) are widespread lowgrowing shrubs with a reputation for causing abortions and unthriftiness in cattle (James et al. 1999). The toxin is suspected to be a diterpene acid (Gardner et al. 1999). Snakeweeds are not usually acceptable to cattle unless lack of forage due to drought, overgrazing, or snow cover forces consumption. Management of snakeweed lies primarily in promoting abundance of alternative forage, including residual forage saved for periodic drought.

Horsebrush (Tetradymia spp.) is a shrub that begins growth early in spring. Sheep often eat horsebrush when stressed from storms or hunger during movement from winter to summer range (Johnson 1978). Tetradymia canescens DC. is reported to be less toxic, but more acceptable to sheep than T. glabrata T. \& G. (Johnson 1978). The toxin is suspected to be the sesquiterpene, tetradymol (Jennings et al. 1978). Horsebrush causes liver damage with or without secondary photosensitization, and photosensitized animals may subsequently develop a swollen head (Johnson 1978). Toxicity from horsebrush is potentiated by prior consumption of black sagebrush (Artemisia nova A. Nels, Johnson 1978), but the mechanism is not known. It is possible that other sagebrush species also potentiate horsebrush toxicity. Losses can largely be avoided by making certain that sheep have adequate feed and do not eat sagebrush before grazing horsebrush-dominated range (Johnson 1978).

\section{Toxic only at certain times and accept- able only at certain times}

Poison hemlock (Conium maculatum L.) is well accepted by livestock, and may even be addictive (Kingsbury 1964, Panter and Keeler 1989). Piperidine alkaloids in poison hemlock stimulate the central nervous system and cause frequent urination and defecation, dilated pupils, increased heart rate, muscular weakness and trembling and ataxia. This initial stage is followed by depression with further muscular weakness, collapse, and death due to respiratory paralysis (Panter et al. 1988). The alkaloids are also potent teratogens that induce skeletal malformations that are indistinguishable from those caused by lupines (Keeler 1978, Panter et al. 1988).

Poison hemlock contains 5 major alkaloids, of which the most toxic alkaloid is $\gamma$-coniceine, (Panter and Keeler 1989). The concentrations and distribution of different alkaloids in poison hemlock are affected by many factors, including environmental changes and plant maturity (Cromwell 1956, Leete and Olson 1972). Drought stress increases total alkaloid concentrations (Fairbairn and Challen 1959). Immature poison hemlock often has a high concentration of $\gamma$-coniceine, which may then be converted predominately into coniine during active growth. During flowering, concentrations of $\gamma$-con- 
iceine also shift to coniine (Cromwell 1956). Thus, coniine is the major alkaloid in mature plants and seed, whereas $\gamma$-coniceine dominates the alkaloid mix in early spring growth and fall regrowth.

The $\gamma$-coniceine is about 8 times more toxic than coniine (Bowman and Sanghvi 1963, Panter et al. 1998), and this difference has important management implications. The most critical time of the year to avoid poison hemlock is spring because the plant often appears before other forage has emerged. Green seed pods may be eaten in mid-to-late summer (Panter and Keeler 1989). Poison hemlock also may regrow in fall after seed shatter. Ingestion during fall may cause fetotoxicity in pregnant cattle if they are in the first trimester (days 30-75, Panter et al. 1988). Even though toxicity decreases upon drying, sufficient toxin may be retained to poison livestock (Galey et al. 1992). Thus, if poison hemlock has invaded hay fields, the contaminated hay can poison livestock. Cattle appear to be particularly susceptible because of their acceptance of the plant and their sensitivity to the teratogenic alkaloids (Panter et al. 2002).

\section{Conclusions}

There is no question that 'poor' range management contributes to livestock losses from poisonous plants and greatly increases risk of losses. Overgrazing will surely increase the risk of losses to some toxic plants. Notwithstanding, plant-animal interactions are very complex, and as Dwyer (1978) pointed out "we are long past the time when we can pass off poisonous plants as a symptom of an overgrazed range." If the mere presence of toxic plants is not an indication of an overgrazed range, what can we conclude about livestock losses in general on rangelands? Our intuition, and Holechek's (2002) data, suggest that many livestock losses are a direct result of 'poor' management, or management errors. Differences in management may be subtle and difficult to verify, particularly if losses are not catastrophic. Is using an inappropriate grazing system 'poor' management? Is it 'poor' management if livestock producers fail to learn what poisonous plants are present on a range, and then lose animals to poisoning? And, is failure to apply existing knowledge another example of 'poor' management? As Pogo said "we have met the enemy and they are us." Nonetheless, some poisonous plants are acceptable to livestock under many differing circumstances (e.g., locoweeds, larkspurs, lupine), and even very careful managers will have losses to these types of plants. Prudent and judicious management can, however, reduce the risk of such losses, and even allow some poisonous plants to be used as nutritious forages at select times.

Research-based recommendations on poisonous plants have reduced livestock losses to many poisonous plants. Perhaps most noticeable of these reduced losses is in teratology, with marked reductions in losses from such plants as veratrum, lupine, and locoweeds (James 1999). Even so, a new and less experienced generation of livestock producer occasionally forgets the lessons of the past with attendant large losses (Chesnut and Wilcox 1901). In 1997 in Adams County, Washington, more than 4000 calves, or $30 \%$ of the population, were born with lupine-induced birth defects (Panter et al. 1999), in part because some livestock producers forgot the harsh lessons learned by an earlier generation. This scenario might be replayed with other toxic plants as experienced range managers and livestock producers are replaced by less-experienced personnel, and as ranches are subdivided or managed by proxy from afar.

New research into potential preventive measures may provide livestock producers with additional tools. Development of vaccines with immunogenic activity against plant toxins in some specific instances may allow animals to eat more of a toxic plant with fewer deaths or production problems (Edgar et al. 1998). Techniques to screen and cull livestock that are susceptible to a specific plant toxin may be practical in the future. Further, genetic heritability may allow producers to breed livestock that are less susceptible to various toxicoses (Launchbaugh et al. 1999, Snowder et al. 2001). For example, the heritability of pulmonary hypertension (high altitude disease) is $78 \%$ in yearling bulls, and high altitude disease has decreased substantially because livestock producers determine pulmonary arterial pressure (PAP) in bulls (Will et al. 1975, Schimmel and Brinks 1982). Risk may also be decreased as livestock producers modify diet selection through food aversion learning or other means (Ralphs et al. 2001). Diet selection is a complex issue, but as we understand in greater depth about when and why animals eat specific poisonous plants, management alternatives will emerge that reduce risk. Further, dietary selection is influenced to some extent by inherited characteristics (Launchbaugh et al. 2000), and it may be possible to alter selection for some toxic plants through breeding programs.

The essence of risk management is to use information from the past to avoid similar losses in the future. The past, however, provides only imperfect knowledge. In our view, the risk of livestock losses to toxic plants will likely continue to diminish as knowledge and understanding increase, but risk will never vanish entirely.

\section{Literature Cited}

Adams, D.C., T.C. Nelsen, W.L. Reynolds, and B.W. Knapp. 1986. Winter grazing activity and forage intake of range cows in the Northern Great Plains. J. Anim. Sci. 62 :1240-1246.

Arnold, G.W. and J.L. Hill. 1972. Chemical factors affecting selection of food plants by ruminants, p. 71-101. In: J.B. Harborne (ed.) Phytochem. Ecol.. Academic Press, London.

Arnold, G.W. and R.W. Maller. 1977. Effects of nutritional experience in early and adult life on the performance and dietary habits of sheep. Appl. Anim. Behav. Sci. 3:5-26.

Baker, D.C., R.A. Smart, M.H. Ralphs, and R.J. Molyneux. 1989. Hound's-tongue (Cynoglossum officinale) poisoning in a calf. J. Amer. Vet. Med. Assoc. 194:929-930.

Basden, K.W. and R.R. Dalvi. 1987. Determination of total phenolics in acorns from different species of oak trees in conjunction with acorn poisoning in cattle. Vet. Hum. Tox. 29:305-306.

Bate-Smith, E.C. 1972. Attractants and repellants in higher animals. p. 45-56. In: J.B. Harborne (ed.). Phytochemical ecology. Academic Press, N.Y.

Bernstein, P.L. 1996. Against the Gods: the remarkable story of risk. John Wiley and Sons, Inc., N.Y.

Binns, W., L.F. James, J.L. Schupe, and E.J. Thacker. 1962. Cyclopian-type malformation in lambs. Arch. Environ. Health 5:106-108.

Bowman, W.C., and I.S. Sanghvi. 1963. Pharmacological actions of hemlock (Conium maculatum) alkaloids. J. Pharm. Pharmacol. 15:1-25.

Burritt, E.A. and F.D. Provenza. 1997. Effect of an unfamiliar location on the consumption of novel and familiar foods by sheep. Appl. Anim. Behav. Sci. 54:317-325.

Chesnut, V.K. and E.V. Wilcox. 1901. The stock-poisoning plants of Montana. USDA Bull. 26. Washington, D.C.

Cooper, S.D.B., I. Kyriazakis, D.H. Anderson, and J.D. Oldham. 1993. The effect of physiological state (late pregnancy) on the diet selection of ewes. Anim. Prod. 56:469A. 
Cosgrove, G.P. and J.H. Niezen. 2000. Intake and selection for white clover by grazing lambs in response to gastrointestinal parasitism. Appl. Anim. Behav. Sci. 66:71-85.

Cromwell, B.T. 1956. The separation, microestimation and distribution of the alkaloids of hemlock (Conium maculatum). Biochem. J. 64:259-266.

Day, J.E.L., I. Kyriazakis, and P.J. Rogers. 1998. Food choice and intake: towards a unifying framework of learning and feeding motivation. Nutr. Res. Rev. 11:25-43.

Dollahite, J.W., G.T. Housholder, and B.J. Camp. 1966. Effect of calcium hydroxide on the toxicity of post oak (Quercus stellata) in calves. J. Amer. Vet. Med. Assoc. 148:908-912.

Duncan, A.J., P. Fructos, and S.A. Young. 2000. The effect of rumen adaptation to oxalic acid on selection of oxalic-acid-rich plants by goats. Brit. J. Nutr. 83:59-65.

du Toit, J.T., F.D. Provenza, and A. Nastis. 1991. Conditioned taste aversions: how sick must a ruminant get before it learns about toxicity in foods. Appl. Anim. Behav. Sci. 30:35-40.

Dwyer, D.D. 1978. Impact of poisonous plants on western U.S. grazing systems and livestock operations. p. 13-21. In: Keeler, R.J., K.R. Van Kampen, and L.F. James (eds.). Effects of poisonous plants on livestock. Academic Press, N.Y.

Edgar, J.A., K.A. Than, A.L. Payne, N. Anderton, J. Baell, Y.Cao, P.A. Cockrum, A. Michalewicz, P.L. Stewart, and J.G. Allen. 1998. Towards a commercial vaccine against lupinosis. p. 196-200. In: T. Garland and A.C. Barr (eds.). Toxic plants and other natural toxicants. CAB International, Wallingford, Oxon, UK

Fairbairn, J.W. and S.B. Challen. 1959. The alkaloids of hemlock (Conium maculatum): distribution in relation to the development of the fruit. Biochem. J. 72:556-561.

Foley, T.D.A., S. McLean, and S.J. Cork. 1995. Consequences of biotransformation of plant secondary metabolites on acid-base metabolism in mammals- a final common pathway? J. Chem. Ecol. 21:721-743.

Foley, W.J., G.R. Iason, and C. McArthur. 1999. Role of plant secondary metabolites in the nutritional ecology of mammalian herbivores- how far have we come in 25 years? $\mathrm{p}$. 130-209. In: H.G. Jung and G.C. Fahey, Jr. (eds.). Nutritional Ecology of Herbivores. Amer. Soc. Anim. Sci., Il.

Foot, J.Z. 1972. A note on the effect of body condition on the voluntary intake of dried grass wafers by Scottish Blackface ewes. Anim. Prod. 14:131-134.

Fredrickson, E.L., R.E. Estell, K.M. Havstad, W.L. Shupe, and L.W. Murray. 2000. The effect of feeding ewe lambs a $15 \%$ tarbush (Flourensia cernua DC) pellet preand post-weaning on the subsequent diet selection of tarbush. J. Arid Environ. 44:123-131.

Freeland, W.J. and D.H. Janzen. 1974. Strategies in herbivory by mammals: the role of plant secondary compounds. Amer. Nat. 108:269-289.
Galey, F.D., D.M. Holstege, and E.G. Fisher. 1992. Toxicosis in dairy cattle exposed to poison hemlock (Conium maculatum) in hay: isolation of Conium alkaloids in plants, hay, and urine. J. Vet. Diagn. Invest. 4:60-64.

Galtier, P. 1999. Biotransformation and fate of mycotoxins. J. Toxic. Toxin Rev. 18:295-312.

Garcia, J. and W.G. Hankins. 1975. The evolution of bitter and the acquisition of toxiphobia. p. 39-45. In: D.A. Denton and J.P Coghlan (eds.), Olfaction and Taste, Vol. 5. Academic Press, N.Y.

Gardner, D.R. and J.A. Pfister. 2000. Late season toxic alkaloid concentrations in tall larkspur (Delphinium spp.) J. Range Manage. 53:331-336.

Gardner D.R., K.E. Panter, and L.F. James. 1999. Pine needle abortion in cattle: metabolism of isocupressic acid. J. Agr. Food Chem. 47:2891-2897.

Gardner, D.R., L.F. James, K.E. Panter, J.A. Pfister, M.H. Ralphs, and B.L. Stegelmeier. 1999. Ponderosa pine and broom snakeweed: poisonous plants that affect livestock. J. Nat. Toxins 8:27-34.

Glendinning, J.I. 1994. Is the bitter rejection response always adaptive? Physiol. Behav. 56:1217-1227.

Hancock, R.D., A.J. Coe, and F.C. de Albite Silva. 1996. Perinatal mortality in lambs in southern Brazil. Trop. Anim. Health Prod. 28:266-272.

Harborne, J.B. 1988. Introduction to ecological biochemistry. $3^{\text {rd }}$ Ed. Academic Press, Inc., San Diego, Calif.

Holechek, J. 2002. Do most livestock losses to poisonous plants result from poor range management? J. Range Manage. in press

Huxtable, C.R., P.R. Dorling, and S.U. Walkley. 1982. Onset and regression of neuroaxonal lesions in sheep with mannosidosis induced experimentally with swainsonine. Acta Neuropathol. 58:27-33.

Illius, A.W., and N.S. Jessop. 1995. Modeling metabolic costs of allelochemical ingestion by foraging herbivores. J. Chem. Ecol. 21:693-719.

Illius, A.W., and N.S. Jessop. 1996. Metabolic constraints on voluntary intake in ruminants. J. Anim. Sci. 74:3052-3062.

James, L.F. 1999. Teratological research at the USDA-ARS Poisonous Plant Research Laboratory. J. Nat. Toxins 8:63-80.

James, L.F. and E.H. Cronin. 1974. Management practices to minimize death losses of sheep grazing halogeton-infested range. J. Range Manage. 27:424-426.

James, L.F., W. Binns, and J.L. Shupe. 1968. Blood changes in cattle and sheep fed lupine. Amer. J. Vet. Res. 29:557-560.

James, L.F., K.E. Panter, B.L. Stegelmeier, D.R. Gardner, and J.A. Pfister. 1999. Principal poisonous plants of the western United States. p. 271-275. In: Current Veterinary Therapy 4: Food Animal Practice. Howard, J.L., and R.A. Smith (eds.). W.B. Saunders Co., Philadelphia, Penn.
James, L.F., R.E. Short, K.E. Panter, R.J. Molyneux, L.D. Stuart, and R.A. Bellows. 1989. Pine needle abortion in cattle: a review and report of 1973-1984 research. Cornell Vet. 79:39-52.

Jennings, P.W., S.K. Reeder, J.C. Hurley, J.E. Robbins, S.K Holian, A. Holian, P. Lee, J.A.S. Pribanic, and M. Hull. 1978. Toxic constituents and hepatotoxicity of the plant Tetradymia glabrata (Asteraceae). p. 217-228. In: Keeler, R.F., K.R. Van Kampen, and L.F. James (eds.). Effects of poisonous plants on livestock. Academic Press, N.Y.

Jessop, N.S. and A.W. Illius. 1997. Modeling animal responses to plant toxicants, $\mathrm{p}$. 243-253. In: J.P.F. D'Mello (ed.) Handbook of Plant and Fungal Toxicants. CRC Press, Boca Raton, Fla.

Johnson, A.E. 1978. Tetradymia toxicity- a new look at an old problem. p. 209-216 In: Keeler, R.F., K.R. Van Kampen, and L.F. James (eds.). Effects of poisonous plants on livestock. Academic Press, N.Y.

Johnson A.E., R.J. Molyneux, and L.D. Stuart. 1985. Toxicity of Riddell's groundsel (Senecio riddellii) to cattle. Amer. J. Vet. Res. 46:577-582.

Keeler, R.F. 1976. Lupin alkaloids from teratogenic and nonteratogenic lupins: III. Identification of anagyrine as the probable teratogen by feeding trials. J. Tox. Environ. Health 1:887-898.

Keeler, R.F. 1978. Reducing incidence of plant-caused congenital deformities in livestock by grazing management. J. Range Manage. 31:355-360.

Keeler, R.F. 1983. Naturally occurring teratogens from plants. p. 161-199. In: R.F. Keeler and A. T. Tu (eds.), Handbook of Natural Toxins. Marcel Dekker, Inc., N.Y.

Keeler, R.F. 1989. Quinolizidine alkaloids in range and grain lupins. p. 133-167. In: P.R. Cheeke (ed.), Toxicants of Plant Origin. Vol. 1, Alkaloids. CRC Press, Boca Raton, Fla.

Keeler, R.F., L.F. James, J.L. Schupe, and K.R. Van Kampen. 1977. Lupine-induced crooked calf disease and a management method to reduce incidence. J. Range Manage. 30:97-102.

Kellerman, T.S. 1987. Activated charcoal as prophylaxis against sensciosis. p. 70. In: Biennial Rep. Vet. Inst., Onderstepoort, So. Africa.

Kingsbury, J.M. 1964. Poisonous plants of the United States and Canada. Prentice-Hall, Inc., Englewood Cliffs, N.J.

Kingsbury, J.M. 1978. Ecology of poisoning, p. 81--91. In: R.F. Keeler, K.R. V an Kampen, and L.F. James (eds.), Effects of poisonous plants on livestock. Academic Press, N.Y.

Krueger, W.C. and L. A. Sharp. 1978 Management approaches to reduce livestock losses from poisonous plants on rangelands. J. Range Manage. 31:347-350.

Kyriazakis, I. and J.D. Oldham. 1993. Diet selection in sheep: the ability of growing lambs to select a diet that meets their crude protein $(\mathrm{N} x 6.25)$ requirements. Br. J. Nutr. 69:617-629. 
Lane, M.A., M.H. Ralphs, J.D. Olsen, F.D. Provenza, and J.A. Pfister. 1990. Conditioned taste aversion: potential for reducing cattle loss to tall larkspur. J. Range Manage. 43:127-131.

Launchbaugh, K.L., and F.D. Provenza. 1994. The effect of flavor concentration and toxin dose on the formation and generalization of flavor aversions in lambs. J. Anim. Sci. 72:10-13.

Launchbaugh, K.L., F.D. Provenza, and J.A. Pfister. 2002. Herbivore response to antiquality factors in forages. J. Range Manage. In press.

Launchbaugh, K.L., J.W. Walker, and C.A. Taylor. 1999. Foraging behavior: experience or inheritance. p. 28-35. In: K.L. Launchbaugh, K.D. Sanders, and J.C. Mosley. (eds.). Grazing behavior of livestock and wildlife. Idaho For. Wildl. and Range Exp. Sta. Bull. No. 70, Moscow, Ida.

Leete, E. and J.O. Olson. 1972. Biosynthesis and metabolism of the hemlock alkaloids. J. Am. Chem. Soc. 94:5472-5477.

McFarlane, I., K.C. Breen, L. DiGiamberardino, and K.L. Moya. 2000. Inhibition of $\mathrm{N}$-glycan processing alters axonal transport of synaptic glycoproteins in vivo. Neurochem. 11:1543-1547.

McLean, A.E.M. and E.K. McLean. 1969. Diet and toxicity. Brit. Med. Bull. 25:278-284.

Mead, R.J., A.J. Oliver, D.R.King, and P.H. Hubach. 1985. The co-evolutionary role of fluoracetate in plant-animal interactions in Australia. Oikos 44:55-60.

Merrill, L.B. and J.L. Schuster. 1978. Grazing management practices affect livestock losses from poisonous plants. J. Range Manage. 31:351-354.

Meyer, M.W. and W.H. Karasov. 1991. Chemical aspects of herbivory in arid and semiarid habitats. p. 167-187. In: Palo, T.R., and C.T. Robbins (eds.). Plant defenses against mammalian herbivory. CRC Press, Boca Raton, Fla.

Molyneux, R.J. and A.E. Johnson. 1984. Extraordinary levels of production of pyrrolizidine alkaloids in Senecio riddellii. J. Nat. Prod. 47:1030-1032.

Molyneux, R.J. and M.H. Ralphs. 1992. Plant toxins and palatability to herbivores. J. Range Manage. 45:13-18.

Noble, J.W., J.D.B. Crossley, B.D. Hill, R.J. Pierce, R.A. McKenzie, M.. Debritz, and A.A. Morley. 1994. Pyrrolizidine alkaloidosis of cattle associated with Senecio lautus. Aust. Vet. J. 71:196-200.

Nolte, D.A., J.R. Mason, and S.L. Lewis. 1994. Tolerance of bitter compounds by an herbivore, Cavia porcellus. J. Chem. Ecol. 20:303-308.

Panciera, R.J. 1978. Oak poisoning in cattle. p. 499-506. In: Keeler, R.J., K.R. Van Kampen, and L.F. James (eds.). Effects of poisonous plants on livestock. Academic Press, N.Y.

Panter, K.E. and L.F. James. 1995. Alkaloid toxicants and teratogens of plant origin. $p$. 145-154. In: D.L. Gustine and H.E. Flores (eds.), Phytochemicals and Health. Amer. Soc. Plant Physiol. Ser., Vol. 15. Rockville, Md.
Panter, K.E. and R.F. Keeler. 1989. Piperidine alkaloids of poison hemlock (Conium maculatum). p. 109-132. In: P.R. Cheeke (ed.), Toxicants of Plant Origin. Vol. 1, Alkaloids. CRC Press, Boca Raton, Fla.

Panter, K.E., D.C. Baker, and P.O. Kechele. 1996. Water hemlock (Cicuta douglasii) toxicoses in sheep: pathologic description and prevention of lesions and death. J. Vet. Diagn. Invest. 8:474-480.

Panter, K.E., D.R. Gardner, and R.J. Molyneux. 1994. Comparison of toxic and teratogenic effects of Lupinus formosus, $L$. arbustus, and $L$. caudatus in goats. J. Nat. Toxins 3:83-93.

Panter, K.E., L.F. James, and D.R. Gardner. 1999. Lupines, poison-hemlock and Nicotiana spp: toxicity and teratogenicity in livestock. J. Nat. Toxins 8:117-134.

Panter, K.E., R.F. Keeler, and D.C. Baker. 1988. Toxicoses in livestock from the hemlocks (Conium and Cicuta spp.). J. Anim. Sci. 66:2407-2413.

Panter, K.E., R.F. Keeler, L.F. James, and T.D. Bunch. 1992. Impact of plant toxins on fetal and neonatal development: a review. J. Range Manage. 45:52-62.

Panter, K.E., M.H. Ralphs, R.A. Smart, and B. Duelke. 1987. Death camas poisoning in sheep: a case report. Vet. Hum. Toxicol. 29:45-48.

Panter, K.E., D.R. Gardner, R.E. Shea, R.J. Molyneux, and L.F. James. 1998. Toxic and teratogenic piperidine alkaloids from Lupinus, Conium, and Nicotiana species. p. 345-350. In: T. Garland and A.C. Barr (eds.), Toxic Plants and Other Natural Toxicants. CAB Intern., Oxon, U.K.

Panter, K.E., D.R. Gardner, C.C. Gay, L.F. James, R. Mills, J.M. Gay, and T.J. Baldwin. 1997. Observations of Lupinus sulphureus-induced "crooked calf disease". J. Range Manage. 50:587-592.

Panter, K.E., L.F. James, D.R. Gardner, M.H. Ralphs, J.A. Pfister, B.L. Stegelmeier, and S.T. Lee. 2002. Influence of management strategies on reproductive losses to poisonous plants. J. Range Manage. In press.

Pascual, J.A., S.L. Fryday, and A.D.M. Hart. 1999. Effects of food restriction on food avoidance and risk of acute poisoning of captive feral pidgeons from fonofos-treated seeds. Arch. Env. Cont. Toxicol. 37:115-124.

Pfister, J.A. and D.C. Adams. 1993. Factors influencing pine needle consumption by grazing cattle during winter. J. Range Manage. 46: 386-390.

Pfister, J.A., K.E. Panter, and D.R. Gardner. 1998. Pine needle consumption by cattle during winter in western South Dakota. J. Range Manage. 51:551-556.

Pfister, J.A., F.D. Provenza, and G.D. Manners. 1990. Ingestion of tall larkspur by cattle: separating effects of flavor from postingestive consequences. J. Chem. Ecol. 16:1697-1705.
Pfister, J.A., G.D. Manners, D.R. Gardner, and M.H. Ralphs. 1994. Toxic alkaloid levels in tall larkspur (Dephinium barbeyi) in western Colorado. J. Range Manage. 47:355-358.

Pfister, J.A., D.C. Adams, M..J. Arambel, J.D. Olsen, and L.F. James. 1989. Sublethal levels of toxic larkspur: effects on intake and rumen dynamics in cattle. Nutr. Rep. Intern.40:629-636.

Pfister, J.A., G.D. Manners, D.R. Gardner, K.W. Price, and M.H. Ralphs. 1996a. Influence of alkaloid concentration on acceptability of tall larkspur (Delphinium spp.) to cattle and sheep. J. Chem. Ecol. 22:1147-1168

Pfister, J.A., G.D. Manners, M.H. Ralphs, Z.X. Hong, and M.A. Lane. 1988. Effects of phenology, site and rumen fill on tall larkspur consumption by cattle. J. Range Manage. 41:509-514.

Pfister, J.A., F.D. Provenza, G.D. Manners, D.R. Gardner, and M.H. Ralphs. 1997a. Tall larkspur ingestion: can cattle regulate intake below toxic levels? J. Chem. Ecol. 23:759-777.

Pfister, J.A., B.L. Stegelmeier, C.D. Cheney, L.F. James, and R.J. Molyneux. 1996b. Operant analysis of chronic locoweed intoxication in sheep. J. Anim. Sci. 74:2622-2632.

Pfister, J.A., M.H. Ralphs, G.D. Manners, D.R. Gardner, K.W. Price, and L.F. James. 1997b. Early season grazing of tall larkspur- (Delphinium spp.) infested rangelands. J. Range Manage. 50: 391-398.

Poage, G.W.III, C.B. Scott, M.G. Bisson, and F.S. Hartmann. 2000. Activated charcoal attenuates bitterweed (Hymenoxys odorata) toxicosis in sheep. J. Range Manage. 53:73-78.

Priolo, A. , G.C. Waghorn, M. Lanza, L. Biondi, and P. Pennisi. 2000. Polyethylene glycol as a means for reducing the impact of condensed tannins in carob pulp: effects on lamb growth, preformance, and meat quality. J. Anim. Sci. 78:810-816.

Provenza, F.D. 1995. Postingestive feedback as an elementary determinant of food preference and intake in ruminants. J. Range Manage. 48:2-17.

Provenza, F.D. 1996. Acquired aversions as the basis for varied diets of ruminants foraging on rangelands. J. Anim. Sci. 74:2010-2020.

Provenza, F.D., J.J. Lynch, and J.V. Nolan. 1993. The relative importance of mother and toxicosis affects the acquisition of food aversions in sheep. J. Chem. Ecol. 19:313-323.

Provenza, F.D., J.A. Pfister, and C.D. Cheney. 1992. Mechanisms of learning in diet selection with reference to phytotoxicosis in herbivores. J. Range Manage. 45:36-45.

Provenza, F.D., J.J. Villalba, C.D. Cheney, and S.J. Werner. 1998. Self-organization of foraging behaviour: From simplicity to complexity without goals. Nutr. Res. Rev. 11:199-222.

Ralphs, M.H. 2002. Ecological relationships between poisonous plants and rangeland condition. J. Range Manage. in press. 
Ralphs, M.H. and C.D. Cheney. 1993. Influence of cattle age, lithium chloride dose level, and food type in the retention of food aversions. J. Anim. Sci. 71:373-379.

Ralphs, M.H. and R.J. Molyneux. 1989. Livestock grazing locoweed and the influence of swainsonine on locoweed palatability and habituation. p. 39-49. In: James, L.F., A.D. Elbein, R.J. Molyneux, and C.D. Warren. (eds.), Swainsonine and related glycosidase inhibitors. Iowa State Univ. Press, Ames, Iowa

Ralphs, M.H. and J.D. Olsen. 1987. Alkaloids and palatability of poisonous plants. p. 78-83. In: USDA Forest Serv. Tech. Rep.

Ralphs, M.H. and B.L. Stegelmeier. 1998. Ability of apomorphine and lithium chloride to create food aversions in cattle. 56:129-137

Ralphs, M.H., D. Graham, M.L. Galyean, and L.F. James. 1997. Research observation: Influence of overwintering feed regimen on consumption of locoweed by steers. J. Range Manage. 50:250-252.

Ralphs, M.H., D. Graham, R.J. Molyneux, and L.F. James. 1993. Seasonal grazing of locoweeds by cattle in northeastern New Mexico. J. Range Manage. 46:416-420.

Ralphs, M.H., L.F. James, D.B. Nielsen, and K.E. Panter. 1984. Management practices reduce cattle loss to locoweed on high mountain range. Rangelands 6(4):175-177.

Ralphs, M.H., F.D. Provenza, J.A. Pfister, D Graham, G.C. Duff, and G. Greathouse. 2001. Conditioned food aversion: from theory to practice. Rangelands 23:14-18.

Robinson, T. 1979. The evolutionary ecology of alkaloids. p. 413-448. In: G.A. Rosenthal and D.H. Janzen. (eds.), Herbivores: Their Interaction with Secondary Plant Metabolites. Academic Press, N.Y.

Schimmel, J.G. and J.S. Brinks. 1982. Relationships of pulmonary arterial blood pressures and postweaning traits in yearling beef bulls. Amer. Soc. Anim. Sci. West. Sec. Proc. 33:203-205.

Schuster, J.L. 1978. Poisonous plant management problems and control measures on U.S. rangelands. p. 23-34. In: Keeler, R.F., K.R. Van Kampen, and L.F. James (eds.). Effects of poisonous plants on livestock. Academic Press, N.Y.

Sharrow, S.H., D.N. Ueckert, and A.E Johnson. 1988. Ecology and toxicology of Senecio species with special reference to Senecio jacobaea, and Senecio longilobus. pp. 181-196. In: L.F. James, M.H. Ralphs, and D.B. Nielsen (eds.). The ecology and economic impact of poisonous plants on livestock production. Westview Press, Boulder, Colo.

Short, R.E., L.F. James, K.E. Panter, R.B. Staigmiller, R.A. Bellows, J. Malcolm, and S.P. Ford. 1992. Effects of feeding ponderosa pine needles during pregnancy: comparative studies with bison, cattle, goats, and sheep. J. Anim. Sci. 70:3498-3504.

Shupe, J.L., W. Binns, L.F. James, and R.F. Keeler. 1967. Lupine, a cause of crooked calf disease. J. Amer. Vet. Med. Assoc. 151:198-203.
Snowder, G.D., J.W. Walker, K.L. Launchbaugh, and L.D. Van Vleck. 2001. Genetic and phenotypic parameters for dietary selection of mountain big sagebrush (Artemisia tridentata Nutt. spp. vaseyana (Rydb.) Beetle) in Rambouillet sheep. J. Anim. Sci. 79:486-492

Stegelmeier, B.L. 1999. Pyrrolizidine alkaloid toxicosis. p. 281-282. In: Current Veterinary Therapy 4: Food Animal Practice. Howard, J.L., and R.A. Smith (eds.). W.B. Saunders Co., Philadelphia, Penn.

Stegelmeier, B.L., L.F. James, K.E. Panter, and R.J. Molyneux. 1995a. Serum swainsonine concentration and $\alpha$-mannosidase activity in cattle and sheep ingesting Oxytropis sericea and Astragalus lentiginosus (locoweeds). Amer. J. Vet. Res. 56:149-154.

Stegelmeier, B.L., L.F. James, K.E. Panter, and R.J. Molyneux. 1995b. Tissue and serum swainsonine concentrations in sheep ingesting Astragalus lentinginosus (locoweed). Vet. Hum. Toxicol. 37:336-339.

Strydom, J.A. and J.P.J. Joubert. 1983. The effect of pre-dosing Homeria pallida Bak. to cattle to prevent poisoning. J. So. Afr. Vet. Assoc. 54:210-203.

Tayler, J.C. 1959. A relationship between weight of internal fat, "fill" and the herbage intake of grazing cattle. Nature 184:2021-2022.

Taylor, C.A. and M.H. Ralphs. 1992. Reducing livestock losses from poisonous plants through grazing management. J. Range Manage. 45:9-12.

Titus, C.H., F. D. Provenza, A. Perevolotsky, and N. Silanikove. 2000. Preferences for foods varying in macronutrients and tannins by lambs supplemented with polyethylene glycol. J. Anim. Sci. 78:1443-1449.

Uresk, D.W. and W.W. Paintner. 1985. Cattle diets in a ponderosa pine forest in the northern Black Hills. J. Range Manage. 38:440-442.

Van Kampen, K.R. and L.F. James. 1970. Sequential development of the lesions in locoweed poisoning. Clin. Toxicol. 5:575-580.

Villalba, J.J. and F.D. Provenza. 1999a. Effects of food structure and nutritional quality and animal nutritional state on intake behaviour and food preferences of sheep. Appl. Anim. Behav. Sci. 63:145-163.

Villalba, J.J. and F.D. Provenza. 1999b. Nutrient-specific preferences by lambs conditioned with intraruminal infusions of starch, casein, and water. J. Anim. Sci. $77: 378-387$

Villalba, J.J. and F.D. Provenza. 2000. Postingestive feedback from starch influences the ingestive behavior of sheep consuming wheat straw. Appl. Anim. Behav. Sci. 66:49-63.

Villalba, J.J., F.D. Provenza, and R.E. Banner. 2000a. Influence of macronutrients and medicines on use of toxin-containing foods by sheep and goats. I. Responses to sagebrush. J. Anim. Sci. (In press)

Villalba, J.J., F.D. Provenza, and R.E. Banner. 2000b. Influence of macronutrients and medicines on use of toxin-containing foods by sheep and goats. II. Responses to quebracho tannin. J. Anim. Sci. (In press). von Leibniz, G.W. 1703. New essays on human understanding. Cambridge Texts in the History of Philosophy, Cambridge University Press, Cambridge, U.K.

Westoby, M. 1974. An analysis of diet selection by large generalist herbivores. Amer. Nat. 108:290-304

Will, D.H., J.L. Hicks, C.S. Card, and A.F. Alexander. 1975. Inherited susceptibility of cattle to high-altitude pulmonary hypertension. J. Appl. Physiol. 38:491-494.

Young, J.A., P.C. Martinelli, R.E. Eckert, Jr., and R.A. Evans. 1999. Halogeton: a history of the mid- $20^{\text {th }}$ century range conservation in the intermountain area. USDA Agr. Res. Serv. Misc. Pub. 1553, Washington, D.C. 